\title{
Faktor-faktor yang Memengaruhi Preferensi Nasabah terhadap Produk Rahn: Studi Kasus PT. BPRS Amanah Ummah
}

\section{Factors Affecting Customer Preferences on Rahn Products: Case Study of PT. BPRS Amanah Ummah}

\author{
Lisda Qotrunnada Nabila Putri ${ }^{1}$, Jaenal Effendi² \\ ${ }^{1}$ Institut Pertanian Bogor, Jalan Raya Dramaga, Bogor 16680, lisdaqotrunnada@ gmail.com \\ ${ }^{2}$ Institut Pertanian Bogor, Jalan Raya Dramaga, Bogor 16680, jaenfendi@gmail.com
}

\begin{abstract}
Rahn is financing for the community to borrow money using personal items as collateral. Public interest in rahn is still small, even though rahn knew as savings and loan services for property that is guaranteed by customers. The savings and loan services are paid every month along with the loan installments and do not use the interest system, only determining the nominal value of the rupiah determined by the pawning party. Thus, this study aims to determine the factors that influence customer preferences in choosing rahn products. The total of 120 respondents are taken, with a proportion of 60 as respondents representing rahn product respondents and 60 other respondents. The collected data is processed using logistic regression techniques. The results of the study show the factors that influence customer preferences for rahn products are factors of knowledge, promotion, service, education level, employment, income, expenditure and the number of dependents significantly influence customer decisions in choosing rahn products.
\end{abstract}

Keywords: BPRS, logistic regression, murtahin, rahn, rahin

\begin{abstract}
Abstrak. Rahn merupakan salah satu pembiayaan bagi masyarakat untuk meminjam uang dengan menggunakan barang-barang pribadi sebagai jaminannya. Ketertarikan masyarakat terhadap rahn masih terbilang cukup kecil, Diketahui bahwa rahn yaitu jasa simpan pinjam atas harta benda yang dijadikan jaminan oleh nasabah. Jasa simpan pinjam tersebut dibayarkan setiap bulannya bersama dengan angsuran kreditnya dan tidak menggunakan sistem bunga, hanya menentukan nominal rupiah yang telah ditentukan oleh pihak penggadai. Penelitian ini bertujuan untuk mengetahui faktor-faktor yang memengaruhi preferensi nasabah dalam memilih produk rahn. Sebanyak 120 responden yang diteliti, dengan proporsi 60 responden merupakan responden produk rahn dan 60 responden lainnya. Data yang terkumpul diolah menggunakan teknik regresi logistik. Hasil penelitian menunjukan bahwa, faktor pengetahuan, promosi, pelayanan, tingkat pendidikan, pekerjaan, pendapatan, pengeluaran dan jumlah tanggungan berpengaruh secara signifikan dalam menentukan keputusan nasabah dalam memilih produk rahn.
\end{abstract}

Kata kunci: BPRS, murtahin, rahn, rahin, regresi logistik

\section{PENDAHULUAN}

Perkembangan industri berbasis syariah di dunia berkembang sangat pesat, salah satunya pada lembaga keuangan syariah baik bank maupun non bank (Surahman \& Adam, 2018). Indonesia merupakan salah satu negara yang memiliki jumlah penduduk Muslim yang mencapai 207 juta jiwa (BPS, 2018). Lembaga keuangan berbasis syariah adalah salah satu alternatif masyarakat dalam memenuhi kebutuhan keuangannya. Berdasarkan UU No. 10 Tahun 1998, lembaga keuangan dibagi menjadi dua yaitu Bank Umum dan Bank Perkreditan Rakyat (BPR). Peraturan Otoritas Jasa Keuangan menyatakan dalam POJK No. 03 Tahun 2016 tentang Bank Pembiayaan Rakyat Syariah yang dalam aktivitasnya tidak dapat dikonversi menjadi Bank Perkreditan Rakyat (BPR).

Bank Pembiayaan Rakyat Syariah (BPRS) yang mengacu pada Peraturan Bank Indonesia No. 11/23/PBI/2009 adalah bank yang dalam kegiatannya diprioritaskan untuk memberikan layanan kepada masyarakat golongan mikro, kecil dan menengah di pedesaan maupun di perkotaan dengan memberikan layanan secara mudah, cepat dan sederhana. Selain itu, salah satu peningkatan dana 
yang berasal dari masyarakat (Dana Pihak Ketiga) yaitu total pendanan dari sumber dana yang diambil dari modal inti dan lembaga lainnya (Yasmin \& Effendi, 2017).

Salah satu produk BPRS yang mendapat respons Fatwa Dewan Syariah Nasional (MUI) adalah Gadai Emas dengan mengeluarkan Fatwa No. 26/DSN-MUI/2002 tentang Gadai Emas dan Fatwa DSN No. 25/DSN-MUI/2002 tentang Rahn (PBI, 2009). Sedangkan menurut PP No.51 Tahun 2011 menyatakan bahwa lembaga-lembaga keuangan seperti perbankan, BPRS dan koperasi syariah telah mengeluarkan produk gadai emas secara terbuka untuk masyarakat.

Rahn merupakan pembiayaan bagi masyarakat dengan menggunakan barang-barang pribadi sebagai jaminannya untuk meminjam uang. Persyaratannya tidak melalui proses yang rumit dan menyulitkan nasabah dalam pemberian dana. Proses pencairannya pun bisa terbilang sangat cepat dan mudah. Hal ini membuat masyarakat tidak harus menunggu lama jika membutuhkan dana saat kondisi krisis dan mendesak (Huda \& Heykal, 2010).

Pada praktiknya, Kredit Cepat Aman (KCA) yang lebih dikenal sebagai gadai konvensional dapat dikatakan sama dengan rahn. Namun, yang membedakan yaitu rahn lebih mengutamakan pada kemaslahatan umat dengan menjauhkan bunga (riba), spekulasi (qimar), dan ketidakpastian (gharar). Hal tersebut menyebabkan tidak akan terjadi unsur kezaliman kepada masyarakat dan nasabah. Pada KCA, diminta biaya tambahan dari uang yang dipinjamkan dan menerapkan sistem bunga (Huda \& Heykal, 2010). KCA lebih dikenal baik oleh masyarakat, padahal rahn hanya mengenal jasa simpan pinjam atas harta benda yang dijadikan jaminan oleh nasabah. Jasa simpan pinjam tersebut dibayarkan setiap bulannya bersama dengan angsuran kreditnya dan simpan pinjam ini tidak menggunakan sistem bunga, hanya menentukan nominal rupiah yang telah ditentukan oleh pihak penggadai. Biasanya hanya membayar tarif jasa sebesar Rp 4,000.00 di setiap bulannya.

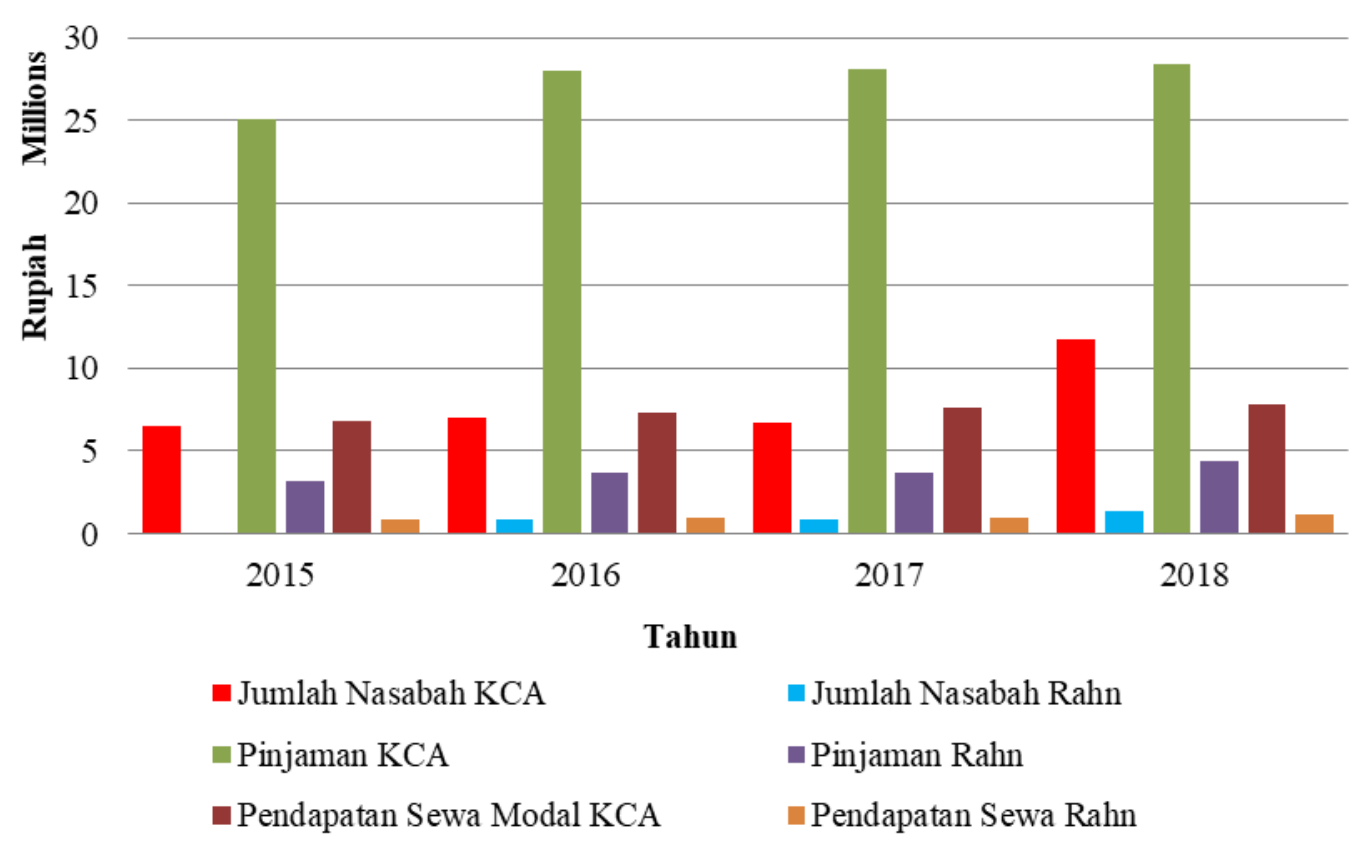

Sumber: Annual Report PT. Pegadaian Persero, 2015-2017

Gambar 1 Perbandingan jumlah nasabah, pinjaman dan pendapatan KCA dan rahn tahun 2015-2017 
Gambar 1 menunjukkan bahwa ketertarikan masyarakat terhadap produk KCA masih mendominasi dilihat dari jumlah nasabah pada tahun 2017 sebesar 6 juta dan meningkat pada tahun 2018 sebesar 11 juta. Sedangkan rahn pada tahun 2017 mencapai 850 ribu dan meningkat sebesar 1.4 juta pada tahun 2018. Untuk jumlah pinjaman, KCA mencapai 28 juta pada tahun 2018 dan rahn sebesar 4 juta. Untuk pendapatan sewa, pada tahun 2018 KCA sebesar 7 juta dan rahn sebesar 1 juta. Jumlah nasabah, pinjaman serta pendapatan KCA mengalami peningkatan yang relatif lebih tinggi dibandingkan rahn. Perkembangan produk rahn terus bertambah setiap tahun. Akan tetapi, ketertarikan masyarakat masih sangat kecil apabila dibandingan dengan KCA.

Sementara itu, transaksi yang digunakan pada rahn tidak menekankan pada sistem bunga dari jumlah pinjaman. Sedangkan pada KCA, transaksi yang digunakan disertai bunga dari jumlah pinjamannya. Pada sistematika hukum jaminan nasional, rahn menjadi salah satu subsistem lembaga jaminan benda bergerak (Setyo, 2010). Menurut Said (2010), keterjangkauan Pegadaian Syariah atau BPRS yang mengeluarkan produk rahn masih cukup kecil. Masyarakat masih kesulitan menemukan produk rahn. Hal ini dapat memengaruhi minat nasabah dalam menggunakan jasa BPRS terkait produk rahn.

Kabupaten Bogor Barat merupakan daerah padat penduduk yang berada di Jawa Barat. Kabupaten Bogor Barat memiliki jumlah penduduk yang mencapai 1 juta jiwa (BPS Kab. Bogor, 2018). Persentase penduduk miskin di Kabupaten Bogor Barat masih terbilang cukup tinggi. Adapun jumlah penduduk miskin di Kabupaten Bogor Barat ditunjukan oleh Tabel 1.

Tabel 1 Penyusunan indikator ekonomi Kabupaten Bogor Barat tahun 2014-2018

\begin{tabular}{ccc}
\hline Tahun & Jumlah Penduduk Miskin (ribu jiwa) & Persentase (\%) \\
\hline 2014 & 470.91 & 9.00 \\
2015 & 475.29 & 8.88 \\
2016 & 480.22 & 8.77 \\
2017 & 485.62 & 8.68 \\
2018 & 491.40 & 8.60 \\
\hline
\end{tabular}

Sumber : BPS Kab. Bogor, 2018

Kabupaten Bogor Barat pada tahun 2014 - 2018 diprediksi memiliki penduduk miskin yang berkisar antara $8 \%$ sampai $9 \%$. Perlu adanya usaha yang keras untuk menggerakan roda perekonomian agar dapat menurunkan tingkat kemiskinan (BPS Kab. Bogor, 2018). Salah satu kecamatan di Kabupaten Bogor Barat yang memiliki rata-rata penduduk berpenghasilan menengah ke bawah yang cukup tinggi yaitu Kecamatan Leuwiliang. Untuk membantu menurunkan tingkat kemiskinan di kecamatan tersebut, BPRS mengeluarkan produk rahn untuk menjadi salah satu pilihan masyarakat.

Salah satu lembaga keuangan berbasis syariah di Kecamatan Leuwiliang adalah BPRS Amanah Ummah. BPRS Amanah Ummah dikelilingi oleh usaha-usaha mikro kecil dan menengah serta pasar. Keberadaan BPRS ini dapat membantu masyarakat dalam memenuhi kebutuhannya, salah satunya kebutuhan untuk mendapatkan uang dengan cara yang mudah dan cepat. BPRS ini terbilang dapat menarik perhatian dengan produk-produk yang ditawarkan, tetapi pengetahuan masyarakat tentang keberadaan BPRS Amanah Ummah masih terbilang cukup kecil. Masyarakat masih banyak yang tidak mengetahui visi dan misi, tujuan serta produk-produk dari BPRS tersebut. BPRS Amanah Ummah telah mengeluarkan beberapa produk pembiayaan, salah satunya rahn. Produk-produk yang ditawarkan diharapkan dapat memberikan gambaran kepada masyarakat untuk melakukan pembiayaan ulang. Salah satu keunggulan produk di BPRS ini mengenai biaya administrasi yang rendah dan prosesnya yang tidak menyulitkan nasabah (Sari dan Sudardjat, 2013). 


\section{TINJAUAN PUSTAKA}

Fatwa MUI No. 25/DSN-MUI/III/2002 tentang Rahn yaitu menahan harta benda atau jaminan atas pinjaman yang diterima oleh peminjam. Harta benda bergerak dan bernilai ekonomis menjadi salah satu barang yang ditahan. Pihak yang menahan (murtahin) akan mendapat jaminan dari barang yang digadaikan. Rahin (orang yang menggadaikan) dapat mengambil kembali barang tersebut jika sebagian atau seluruh piutangnya telah terlunasi.

Berdasarkan Qs. Al-Baqarah ayat 283, Allah berfirman :

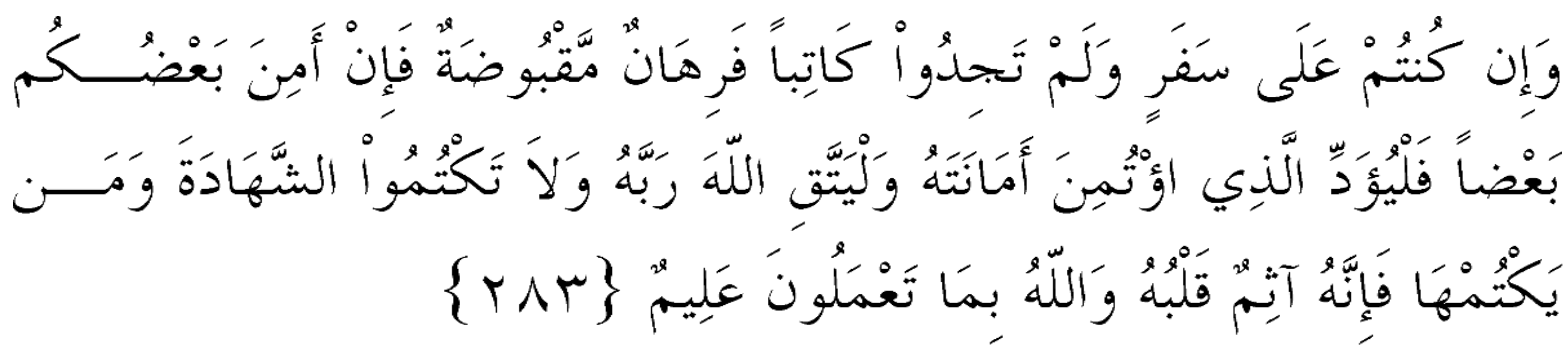

Jika kamu dalam perjalanan (dan bermu amalah tidak secara tunai) sedang kamu tidak memperoleh seorang penulis, maka hendaklah ada barang tanggungan yang dipegang (oleh yang berpiutang). Akan tetapi jika sebagian kamu mempercayai sebagian yang lain, maka hendaklah yang dipercayai itu menunaikan amanatnya (utangnya) dan hendaklah ia bertakwa kepada Allah Tuhannya; dan janganlah kaтu (para saksi) menyembunyikan persaksian. Dan barangsiapa yang menyembunyikannya, maka sesungguhnya ia adalah orang yang berdosa hatinya; dan Allah Maha Mengetahui apa yang kamu kerjakan.

Beberapa rukun rahn yang perlu dipenuhi (Huda \& Heykal, 2010) antara lain:

1. Orang yang menggadaikan (rahin)

Berakal, balig, dapat dipercaya, dewasa, dan memiliki barang yang akan digadaikan.

2. Orang yang menerima gadai (murtahin)

Lembaga, bank atau orang yang dapat dipercaya rahin untuk mendapatkan modal dengan barang yang dijadikan jaminan (gadai).

3. Barang yang akan digadaikan (marhun)

Barang yang dapat dijadikan jaminan rahin untuk mendapatkan pinjaman atau utang.

4. Utang (marhun bih)

Sejumlah dana yang diberikan murtahin kepada rahin atas dasar taksiran harta benda yang digadaikan,

5. Sighat, ijab dan qabul

Kesepakatan anatara rahin dan murtahin dalam melakukan transaksi gadai.

Beberapa syarat yang digunakan untuk produk rahn (Huda \& Heykal, 2010) antara lain:

1. Rahin dan Murtahin

Setiap pihak yang melakukan perjanjian gadai harus memiliki kemampuan diri dan berakal sehat.

Kemampuan di sini dapat diartikan sebagai kelayakan seseorang dalam melakukan transaksi kepemilikan.

2. Syarat Gadai

a. Sighat, tidak boleh terikat dengan syarat tertentu dan juga dengan waktu di masa depan.

b. Rahn, memiliki sisi pemberian utang dan tidak boleh diikat dengan syarat tertentu atau dengan waktu tertentu.

3. Utang (Marhun Bih)

a. Marhun harus benda berwujud dan diserahkan ketika terjadi utang.

b. Memungkinkan untuk dimanfaatkan, akan tidak sah ketika utang tidak bisa dimanfaatkan.

c. Bisa dihitung dan diukur jumlah dan kadarnya. Barang tersebut tidak sah jika tidak dapat diukur. 
4. Barang (Marhun)

Harus benda berwujud, bernilai ekonomis, dapat diukur, benda bergerak, dan dapat diserahkan saat terjadi utang.

Tabel 2 Hak dan kewajiban

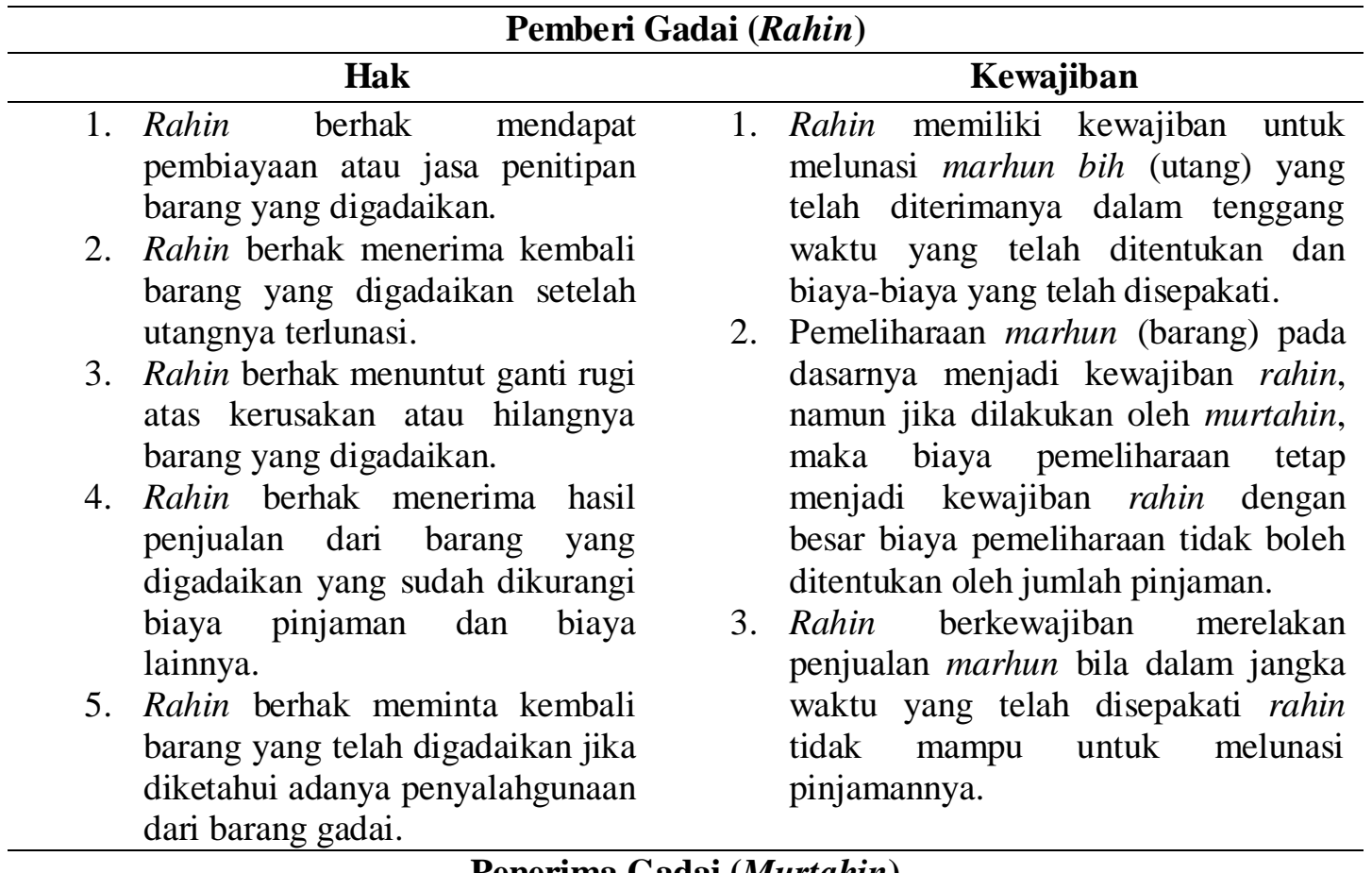

Hak

Kewajiban

1. Murtahin mendapatakan biaya administrasi dan pemeliharaan yang telah dikeluarkan oleh rahin untuk menjaga keselamatan barang yang telah digadaikan.

2. Murtahin mempunyai hak untuk menahan marhun sampai semua marhun bih terlunasi.

3. Apabila rahin tidak membayar sebagian atau seluruh piutangnya dalam jangka waktu yang telah ditentukan, murtahin berhak untuk menjual barang tersebut dan hasil penjualannya diambil sebagian untuk melunasi utang rahin dan sisanya di kembalikan kepada rahin.

Sumber: Huda \& Heykal, 2010

1. Murtahin harus bertanggung jawab atas hilang atau menurunnya harga marhun bila itu disebabkan oleh kelalaian.

2. Murtahin tidak boleh mementingkan kepentingan pribadi dalam menggunakan marhun.

3. Murtahin berkewajiban memberikan informasi kepada rahin sebelum melakukan pelelangan barang gadai. 
Tabel 3 Perbandingan gadai syariah dan konvensional

\begin{tabular}{|c|c|c|}
\hline & Gadai Syariah (Rahn) & Gadai Konvensional (KCA) \\
\hline Pengertian & $\begin{array}{l}\text { Definisi al-rahn menurut istilah } \\
\text { adalah menjadikan suatu benda yang } \\
\text { mempunyai nilai harta untuk } \\
\text { jaminan suatu utang, sehingga } \\
\text { memungkinkan untuk mengambil } \\
\text { sebagian atau seluruh utang dari } \\
\text { benda tersebut (Azizah, 2018). }\end{array}$ & $\begin{array}{l}\text { Suatu hak yang diperoleh seseorang } \\
\text { yang berpiutang atas suatu benda } \\
\text { bergerak, yang diserahkan } \\
\text { kepadanya dan memberikan } \\
\text { kekuasaan kepada orang yang } \\
\text { berpiutang untuk mengambil } \\
\text { pelunasan dari barang tersebut } \\
\text { (Mubarak \& Windasari, 2014). }\end{array}$ \\
\hline $\begin{array}{l}\text { Dasar } \\
\text { Hukum }\end{array}$ & $\begin{array}{l}\text { 1. Quran (Qs. Al-Baqarah ayat 283) } \\
\text { 2. Hadis } \\
\text { 3. Ijma Ulama } \\
\text { 4. Fatwa Dewan Syariah Nasional } \\
\text { Majelis Ulama Indonesia (DSN- } \\
\text { MUI) }\end{array}$ & $\begin{array}{l}\text { Undang-undang Hukum Perdata, } \\
\text { pasal } 1150 \text { sampai } 1160 \text { tentang } \\
\text { pegadaian. }\end{array}$ \\
\hline $\begin{array}{l}\text { Produk } \\
\text { dan Jasa }\end{array}$ & $\begin{array}{l}\text { 1. Gadai Syariah (Rahn) } \\
\text { 2. ARRUM (Ar-Rahn untuk Usaha } \\
\text { Mikro/Kecil) } \\
\text { 3. Amanah } \\
\text { 4. MULIA (Murabahah Logam } \\
\text { Mulia untuk Investasi Abadi) } \\
\text { 5. Tabungan Emas } \\
\text { 6. Konsinyasi Emas } \\
\text { 7. Multi Pembayaran Online } \\
\text { 8. Arrum Haji }\end{array}$ & $\begin{array}{ll}\text { 1. } & \text { Kredit Cepat Aman (KCA) } \\
\text { 2. } & \text { Kredit Angsuran Sistem Gadai } \\
\text { (Krasida) } \\
\text { 3. } \\
\text { Kredit Angsuran Sistem } \\
\text { Fidusia (Kreasi) } \\
\text { 4. } & \text { Kredit Serba Guna (Kresna) } \\
\text { Kredit Usaha Rumah Tangga } \\
\text { 6. } \\
\text { 7. } & \text { Galeri } 24 \\
\end{array}$ \\
\hline
\end{tabular}

Sumber: Ilustrasi penulis, 2019

Preferensi merupakan suatu pilihan yang dibuat konsumen untuk produk-produk yang mereka konsumsi. Preferensi adalah suatu kecenderungan dari seseorang dalam mengutamakan dan memilih di antara dua pilihan. Seseorang akan mengutamakan suatu pilihan yang dianggap lebih baik yang akan dilakukan tanpa adanya paksaan. Sedangkan menurut Kotler (2000), preferensi merupakan ketertarikan konsumen pada beberapa pilihan produk dan jasa. Dapat disimpulkan bahwa preferensi konsumen dapat diketahui dengan menganalisis tingkat kepuasan dengan mengukur kegunaan dan nilai yang menjadi atribut pada suatu produk dan jasa. Atribut pada produk atau jasa menjadi daya tarik dan konsumen terhadap pemilihan produk atau jasa.

Hal tersebut akan menggambarkan dan mencerminkan sikap dan perilaku konsumen dalam mengonsumsi suatu produk atau jasa. Selain itu, keputusan konsumen sangat erat hubungannya dengan perilaku konsumen. Perusahaan harus mengerti bagaimana konsumen akan memilih produk, harga, dan rangsangan terhadap iklan yang dilakukan untuk menunjukkan keunggulan dari pesaingnya. Karena konsumen merupakan salah satu unsur terpenting dalam pemasaran yang menjadi perhatian bagi sebuah lembaga bisnis (Siregar, 2018).

Menurut Howard (1989), preferensi dipengaruhi oleh lima faktor:

1. Faktor Kebudayaan

Faktor ini merupakan faktor dasar dari perilaku keinginan seseorang yang ditentukan oleh nilainilai dasar, norma-norma, prinsip, dan sikap dalam memantaskan perilaku.

2. Faktor Sosial

Faktor ini dipengaruhi oleh status sosial, kelas sosial dan keberadaan keluarga yang dapat memperlihatkan perbedaan dalam suatu interaksi. Contohnya yaitu tingkat pendidikan dan jumlah keluarga. 
3. Faktor Pribadi

Faktor ini dipengaruhi oleh adanya perbedaan antar status sosial baik usia muda dan tua, memiliki pekerjaan atau tidak, sehingga dapat terlihat gaya hidup dari perbedaan masing-masing individu tersebut. Contohnya usia dan pekerjaan.

4. Faktor Ekonomi

Faktor ini dapat ditentukan oleh perbedaan terhadap kondisi keuangan masing-masing individu yang terlihat dari penerimaan, upah, gaji, dan insentif yang didapat dari aktivitas individu tersebut. Contohnya yaitu pendapatan dan pengeluaran.

5. Faktor Psikologis

Faktor ini ditentukan dengan adanya suatu dorongan, rangsangan, motivasi, dan persepsi terhadap perilaku suatu individu yang dapat memperlihatkan suatu pengambilan keputusan sesuai dengan tujuan yang ingin dicapai. Contohnya yaitu pengetahuan, citra lembaga, aksesibilitas, promosi, dan pelayanan.

\section{METODE}

Penelitian ini menggunakan sumber data utama yaitu data primer dan data sekunder sebagai data pendukung. Peneliti menggunakan jenis data kualitatif dengan wawancara dan menyebar kuesioner kepada nasabah rahn dan pembiayaan lainnya. Data primer ini diperkuat oleh data sekunder yang diperoleh dari preferensi jurnal nasional dan internasional, penelitian terdahulu, dan buku. Literatur yang digunakan antara lain didapatkan melalui Badan Pusat Statistik (BPS), Peraturan OJK, Peraturan BI, PT. Pegadaian, serta penelitian lain sebagai referensi pendukung pada penelitian ini.

Penelitian ini dilakukan di PT. BPRS Amanah Ummah Leuwiliang Bogor yang beralamat di Jl. Raya Leuwiliang No. 9 Bogor Barat. Waktu yang digunakan dalam penelitian ini selama dua bulan, yaitu bulan Januari sampai dengan bulan Februari 2019. Metode pengambilan sampling dalam penelitian ini menggunakan metode non probability sampling yaitu jenis sampling yang dilakukan secara tidak acak, sehingga tidak semua populasi bisa menjadi sampel, hanya sebagian saja yang akan menjadi sampel karena faktor kebetulan atau sesuatu yang telah ditentukan oleh peneliti.

Cara pengambilan sampel penelitian ini menggunakan teknik purposive sampling, yaitu sampel yang diambil berdasarkan informasi yang diketahui suatu populasi (Sugiyono, 2011). Jumlah populasi dalam penelitian ini adalah seluruh nasabah pembiayaan dan tabungan di PT. BPRS Amanah Ummah. Dalam penelitian penulis mempersempit populasi yaitu jumlah nasabah sebanyak 1,000 orang dengan menghitung ukuran sampel dengan menggunakan teknik Slovin (Sugiyono, 2011).

Rumus Slovin untuk menentukan sampel adalah sebagai berikut:

$$
\mathrm{n}=\frac{\mathrm{N}}{1+N(e)^{2}}
$$

Keterangan:

$\mathrm{n}=$ Ukuran sampel/jumlah responden

$\mathrm{N}=$ Ukuran populasi

$\mathrm{e}=$ Persentase kelonggaran ketelitian kesalahan pengambilan sampel yang masih bisa ditolerir

Jumlah populasi dalam penelitian ini sebanyak 1,000 nasabah, sehingga persentase kelonggaran yang digunakan adalah $10 \%$ dan hasil perhitungan dapat dibulatkan untuk mencapai kesesuaian, dengan perhitungan sebagai berikut:

$$
\begin{aligned}
& \mathrm{n}=\frac{1,000}{1+1,000(0.01)} \\
& \mathrm{n}=\frac{1,000}{11}
\end{aligned}
$$


$\mathrm{n}=90.9 ;$ disesuaikan oleh peneliti menjadi 100 responden.

Berdasarkan perhitungan di atas, sampel yang menjadi responden dalam penelitian ini disesuaikan menjadi 100 orang dengan cadangan responden sebanyak 20 orang. Maka seluruh total responden dari nasabah di PT. BPRS Amanah Ummah sebanyak 120 orang. Pemberian kuesioner dan wawancara diberikan kepada 120 orang yaitu nasabah pembiayaan produk rahn sebanyak 60 responden dan nasabah pembiayaan lain dan tabungan sebanyak 60 responden. Dalam penelitian ini, metode analisis data yang digunakan mencakup analisis deskriptif, analisis skala Likert dan metode analisis regresi logistik.

\section{Analisis Deskriptif}

Analisis deskriptif yang digunakan untuk mengambil data terkait tujuan penelitian yaitu untuk mengkaji karakteristik responden pada BPRS Amanah Ummah. Analisis deskriptif mencakup tabulasi dan grafik yang menjelaskan data yang bersifat kuantitatif maupun kualitatif.

\section{Analisis Regresi Logistik}

Model regresi logistik adalah metode yang digunakan untuk menjelaskan faktor-faktor yang memengaruhi preferensi nasabah dalam memilih rahn. Menurut Firdaus \& Harmini (2011), analisis ini mengkaji hubungan pengaruh peubah penjelas terhadap peubah respons melalui model persamaan matematis tertentu. Model persamaan regresi yang digunakan dalam penelitian ini adalah sebagai berikut:

$$
\begin{aligned}
\mathrm{Y} i= & \beta+\beta 1 \mathrm{X} 1+\beta 2 \mathrm{X} 2+\beta 3 \mathrm{X} 3+\beta 4 \mathrm{X} 4+\beta 5 \mathrm{X} 5+\beta 6 \mathrm{X} 6+\beta 7 \mathrm{X} 7+\beta 8 \mathrm{X} 8+\beta 9 \mathrm{X} 9+ \\
& \beta 10 \mathrm{X} 10+\beta 11 \mathrm{X} 11+\varepsilon
\end{aligned}
$$

Keterangan :

Yi : Keputusan nasabah memilih rahn (1 jika memilih rahn, 0 jika tidak memilih rahn)

$\beta$ : Intersep

$\beta \mathrm{i}:$ Paramater peubah Xi

$\varepsilon:$ Error

$\mathrm{X} 1:$ Usia responden (tahun)

$\mathrm{X} 2$ : Tingkat pendidikan (tahun)

$\mathrm{X} 3$ : Pekerjaan

X4 : Pendapatan (rupiah)

$\mathrm{X} 5$ : Pengeluaran rumah tangga (rupiah)

X6 : Jumlah tanggungan keluarga (orang)

X7 : Pengetahuan (skala Likert)

X8 : Citra lembaga (skala Likert)

X9: Aksesibilitas (skala Likert)

X10 : Promosi (skala Likert)

X11 : Pelayanan (skala Likert)

Odds ratio digunakan sebagai peluang terjadinya pilihan 1 (memilih rahn) terhadap peluang terjadinya pilihan 0 (tidak memilih rahn) .Nilai odds yang semakin besar menunjukkan peluang nasabah untuk memilih rahn semakin besar. Nilai odds merupakan indikator kecenderungan nasabah untuk menentukan pilihan 1 (memilih rahn). Hubungan antara parameter dan odds ratio yaitu:

Odds Ratio $=\frac{P i}{1-P i}$

Keterangan:

Pi : Rasio peluang terjadinya pilihan 1 


\section{PEMBAHASAN}

BPRS Amanah Ummah berkantor pusat di Kabupaten Bogor, tepatnya berlokasi di Jalan Raya Leuwiliang No. 9 Leuwiliang, Kabupaten Bogor, Provinsi Jawa Barat. Lokasi BPRS Amanah Ummah ini sangat strategis untuk menjangkau masyarakat sekitar karena berada di dekat pasar tradisional dan berada di dekat jalan raya Leuwiliang. BPRS Amanah Ummah memiliki visi menjadi BPRS pilihan umat, serta menjadi BPRS yang amanah dan profesional. Sedangkan misi yang dimiliki BPRS Amanah Ummah yaitu membangun kualitas kehidupan umat melalui perbankan syariah. Selanjutnya, moto yang dimiliki BPRS Amanah Ummah yaitu 'Menepis Riba Meraih Laba Mengandung Berkah'. BPRS Amanah Ummah memiliki tiga budaya kerja yaitu pelayanan cepat, amanah dan profesional.

Akad penyerahan barang (emas) dari nasabah (rahin) kepada bank (murtahin) sebagai jaminan untuk mendapatkan utang. Sistem teknis operasional produk rahn dapat dilihat pada Gambar 2.
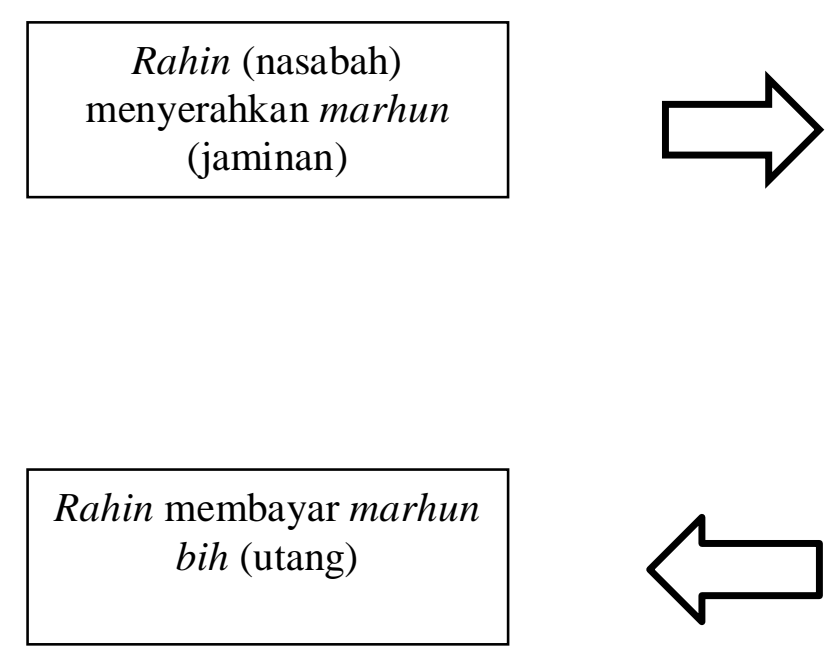
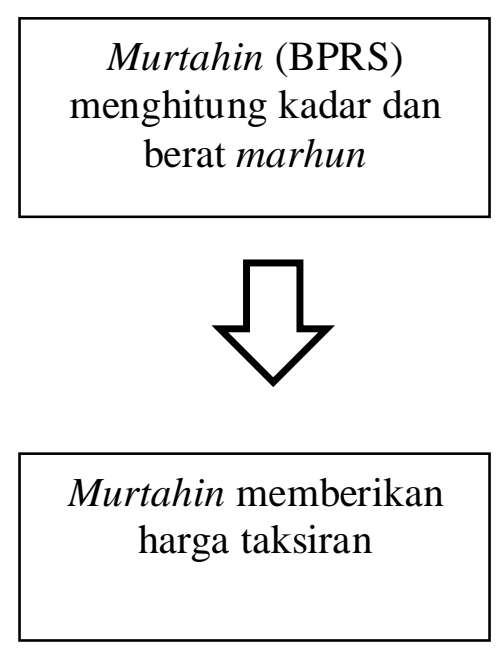

Sumber: Ilustrasi penulis, 2019

Gambar 2 Teknis operasional produk rahn

Manfaat dan kemudahan transaksi di BPRS Amanah Ummah:

1. Proses yang mudah dan cepat, pencairan dana relatif lebih singkat dengan waktu yang kurang dari 10 menit.

2. Sesuai dengan syariah bebas dari riba.

3. Asuransi barang jaminan sesuai dengan syariah.

4. Biaya adminstrasi dan pemeliharaan relatif lebih murah mulai $\mathrm{Rp} 1,500.00 / \mathrm{gr} / 30$ hari.

5. Jangka waktu fleksibel (maksimal 2 bulan dan dapat diperpanjang).

Syarat administrasi di BPRS Amanah Ummah:

1. Fotokopi KTP/SIM/Paspor atau identitas lainnya yang masih berlaku.

2. Jaminan berupa emas.

Produk rahn:

1. Emas Perhiasan/Batangan

a. Petugas melihat standar taksiran logam yang telah ditetapkan oleh kantor pusat. Harga penaksiran sesuai dengan perkembangan harga di pasaran.

b. Petugas penaksiran melakukan pengecekan berat emas dan kadar emas.

c. Petugas penaksiran menentukan nilai taksirannya. 
Akad yang digunakan untuk menjalankan produk rahn:

1. Akad Rahn

Rahn (gadai syariah) yaitu menahan salah satu harta benda milik peminjam atas pinjaman yang didapatkan atau diterima. Syarat objek gadai tersebut salah satunya harus bernilai ekonomis agar pihak penahan dapat memperoleh jaminan dan pihak peminjam dapat mengambil kembali sebagian atau seluruh piutangnya.

2. Akad Qardh

Akad penghimpun dana bagi bank yang melaksanakan aktivitas usahanya berdasarkan syariat Islam yang diatur dalam ketentuan BI pasal 1 ayat 11 No. 7/46/PBI/2005 tentang akad penghimpun dana. Dimana peminjam meminjam dana dengan kewajiban pihak yang meminjam mengembalikan pokok pinjamannya tanpa imbalan secara angsuran dalam jangka waktu tertentu atau sekaligus disebut dengan qardh.

3. Akad Ijarah

Akad pemindahan hak guna atas jasa dan barang melalui pembayaran upah dan sewa yang memungkinkan pegadaian untuk menarik biaya sewa tanpa diikuti dengan pemindahan kepemilikan atas barang yang digadaikan.

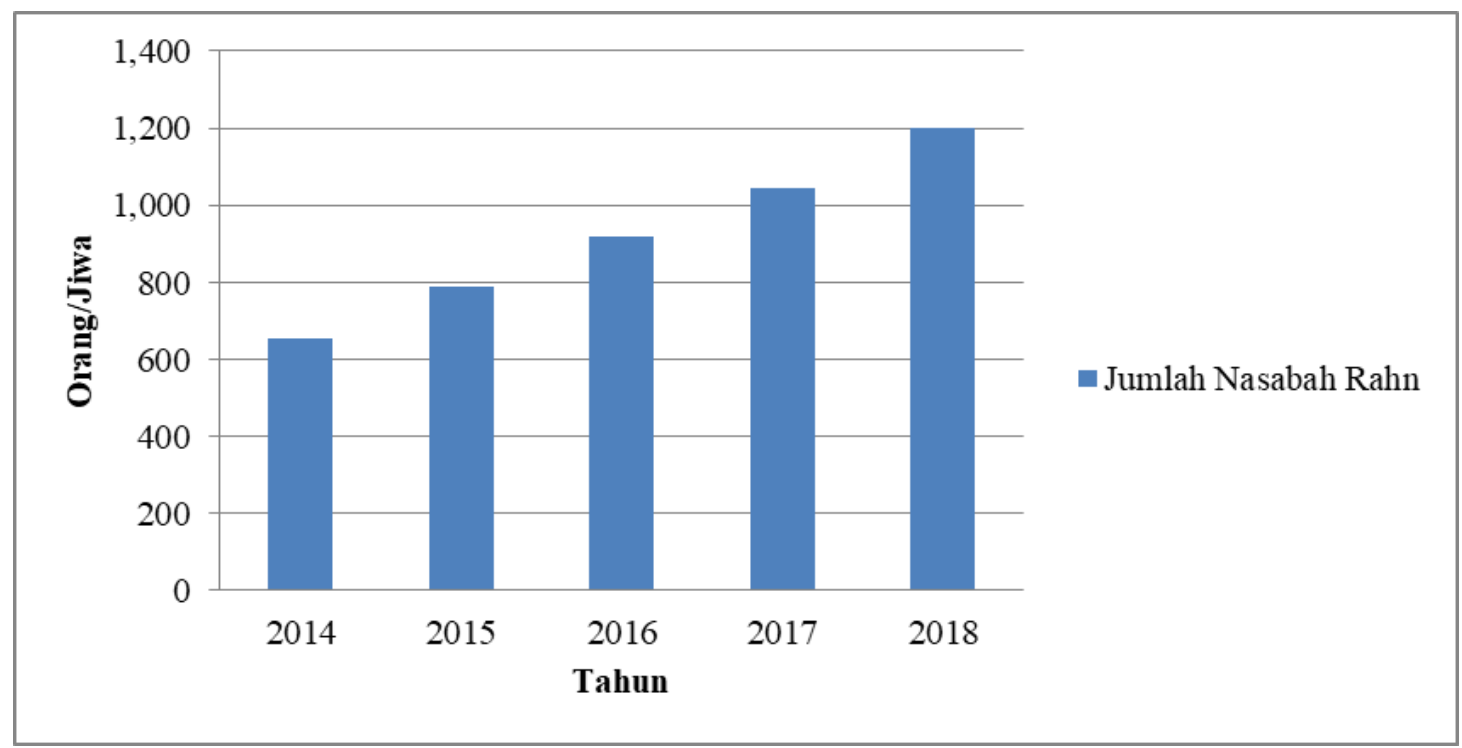

Sumber: Data Primer, 2019 (diolah)

Gambar 3 Jumlah nasabah rahn di BPRS Amanah Ummah

Gambar 3 menunjukkan bahwa jumlah nasabah produk rahn di BPRS Amanah Ummah memiliki peningkatan di setiap tahunnya. Peningkatan jumlah nasabah dari tahun 2014 sampai 2017 mencapai 1,000 orang dan mengalami peningatan di tahun 2018 mencapai 1,200 orang. Peningkatan tersebut dikarenakan adanya kebutuhan masyarakat yang harus dipenuhi. Salah satunya untuk tambahan modal usaha, membayar pendidikan sekolah, dan kebutuhan penunjang lainnya. Produk rahn menjadi solusi untuk memenuhi kebutuhan tersebut dengan syarat dan proses yang tidak menyulitkan nasabah sehingga proses pencairan dana dapat dilakukan secara cepat. Strategi peningkatan jumlah nasabah menurut Jannah (2018) yaitu menggunakan metode marketing mix (bauran pemasaran) yang bertujuan untuk mencapai target yang diinginkan BPRS. Strategi yang dilakukan yaitu:

1. Memberikan pelayanan secara maksimal kepada calon nasabah dan nasabah lama.

2. Membuat inovasi pada produk, layanan dan fasilitas.

3. Mempertahankan nasabah lama dengan memberikan kenyamaan di dalam bertransaksi dan membuat suasana kekeluargaan antara karyawan dan nasabah.

4. Mencari nasabah baru dengan melakukan promosi melalui media cetak maupun media elektronik dan mengunjungi pasar-pasar untuk melakukan pemasaran secara opentable (melalui pameran). 


\section{Karakteristik Responden berdasarkan Aspek Sosial}

Tabel 4 Karakteristik responden berdasarkan aspek sosial

\begin{tabular}{cccc}
\hline Kategori & Keterangan & $\begin{array}{c}\text { Memilih } \text { Rahn } \\
(\%)\end{array}$ & $\begin{array}{c}\text { Tidak Memilih Rahn } \\
\text { (\%) }\end{array}$ \\
\hline \multirow{3}{*}{ Umur (Tahun) } & $20-30$ & 5 & 35 \\
& $31-40$ & 55 & 28 \\
& $41-50$ & 27 & 22 \\
Jenis Kelamin & $>50$ & 13 & 15 \\
& Laki-laki & 23 & 42 \\
& Perempuan & 77 & 58 \\
\hline \multirow{3}{*}{ Tingkat Pendidikan } & SD & 6 & 0 \\
& SMP & 20 & 17 \\
& SMA & 50 & 42 \\
& D3 & 12 & 10 \\
& S1 & 12 & 31 \\
\hline \multirow{3}{*}{ Jumlah Tanggungan } & 1 & 0 & 0 \\
Keluarga (Jiwa) & 2 & 8 & 20 \\
& 3 & 18 & 20 \\
& 4 & 43 & 20 \\
& 5 & 23 & 15
\end{tabular}

Sumber : Data primer, 2019 (diolah)

Karakteristik responden (nasabah) pada Tabel 4 dapat dilihat berdasarkan usia, yang dibagi menjadi empat kategori. Usia yang memilih produk rahn di BPRS Amanah Ummah didominasi oleh responden pada rentang usia 31 sampai 40 tahun sebanyak 33 orang (55\%). Hal tersebut menunjukkan bahwa responden yang memilih produk rahn didominasi oleh usia tua. Pemilihan tersebut dipengaruhi oleh adanya kebutuhan di masa tua yang lebih banyak dibandingkan kebutuhan di masa muda. Usia yang tidak memilih produk rahn didominasi oleh responden pada rentang usia 20-30 tahun sebanyak 21 orang $(35 \%)$. Hal tersebut menunjukkan bahwa responden yang tidak memilih produk rahn didominasi oleh usia muda. Pemilihan tersebut didasari adanya prioritas untuk aktivitas menabung, sehingga produk yang dipilih bukanlah produk rahn.

Berdasarkan jenis kelamin, responden yang memilih produk rahn di BPRS Amanah Ummah didominasi oleh perempuan, yaitu $77 \%$ atau 46 orang perempuan dari 60 responden yang memilih produk rahn. Sedangkan responden yang tidak memilih produk rahn $58 \%$ atau 35 orang perempuan dari 60 responden. Hal ini menunjukkan bahwa perempuan memiliki jumlah pengeluaran yang relatif banyak, sehingga dibutuhkannya dana tambahan untuk memenuhi kebutuhannya.

Berdasarkan tingkat pendidikan, responden yang memilih produk rahn dan tidak memilih produk rahn dibagi menjadi enam kategori, yaitu: Sekolah dasar (SD), Sekolah Menengah Pertama (SMP), Sekolah menengah Atas (SMA), Diploma (D3), dan Sarjana (S1). Tingkat pendidikan paling banyak dari responden yang memilih produk rahn adalah 50\% atau sebanyak 30 orang SMA. Kemudian yang paling sedikit adalah $6 \%$ atau sebanyak 4 orang SD. Sementara, responden yang tidak memilih rahn didominasi oleh $42 \%$ atau sebanyak 25 orang tingkat pendidikan SMA. Kemudian yang paling sedikit adalah $10 \%$ atau sebanyak 6 orang D3. Hal ini menunjukkan bahwa tingkat pendidikan dapat memengaruhi responden untuk memilih produk rahn karena persyaratannya yang mudah dan pencairan dana yang cepat membuat responden mengerti dengan cepat. 
Berdasarkan jumlah tanggungan responden yang memilih produk rahn, mayoritas tanggungannya adalah 4 orang, yaitu $43 \%$ atau 25 orang. Sedangkan yang tidak memilih rahn tanggungannya adalah 3 orang, yaitu 25\% atau 15 orang. Hal ini menunjukkan bahwa semakin banyak jumlah tanggungan seseorang, maka semakin banyak pula kebutuhan akan dana tambahan yang diperlukan.

\section{Karakteristik Responden berdasarkan Aspek Ekonomi}

Dapat dilihat dari rata-rata pendapatan, pengeluaran dan jenis pekerjaan responden.

a. Pendapatan dan pengeluaran responden

Sumber pendapatan responden setiap bulannya dapat dilihat pada Tabel 5. Karakteristik sumber pendapatan dan pengeluaran responden berasal dari pekerjaan utama. Rata-rata sumber pendapatan nasabah yang memilih produk rahn berada pada rentang 1 juta rupiah sampai 5 juta rupiah sebesar $73 \%$ atau 44 orang. Sedangkan rata-rata sumber pendapatan nasabah yang tidak memilih produk rahn berada pada rentang 5 juta rupiah sampai 10 juta rupiah sebesar $73 \%$ atau 44 orang. Hal ini menunjukkan bahwa semakin besar jumlah pendapatan seseorang, maka kebutuhan akan dana tambahan semakin sedikit. Sedangkan responden yang memiliki jumlah pendapatan yang rendah, maka kebutuhan akan dana tambahan semakin besar yang membuat responden merasa terpenuhi dengan adanya produk rahn.

Sumber pengeluaran nasabah yang memilih produk rahn dan yang tidak memilih produk rahn berada pada rentang 1 juta rupiah sampai 5 juta rupiah sebanyak $77 \%$ atau 46 orang dan sebanyak $82 \%$ atau 49 orang. Hal ini menunjukkan bahwa dengan adanya produk rahn responden tidak kesulitan dalam mencari dana tambahan untuk memenuhi kebutuhan pribadinya.

Tabel 5 Pendapatan dan pengeluaran responden

\begin{tabular}{ccc}
\hline Pendapatan (Rp) & Memilih Produk Rahn (\%) & Tidak Memilih Rahn $(\%)$ \\
\hline$<1,000,000$ & 0 & 0 \\
$1,000,001-5,000,000$ & 73 & 12 \\
$5,000,001-10,000,000$ & 18 & 13 \\
$>10,000,001$ & 15 & 0 \\
\hline Pengeluaran (Rp) & Memilih Produk Rahn (\%) & Tidak Memilih Rahn $(\%)$ \\
\hline$<1,000,000$ & 0 & 82 \\
$1,000,001-5,000,000$ & 77 & 3 \\
$5,000,001-10,000,000$ & 23 & 3 \\
$>10,000,001$ & 0 &
\end{tabular}

Sumber : Data primer, 2019 (diolah)

b. Jenis pekerjaan responden

Jenis pekerjaan responden yang memilih produk rahn dan tidak memilih produk rahn mempunyai pekerjaan yang beragam, yaitu wiraswasta, PNS/BUMN, pegawai swasta, pensiunan, dan Ibu Rumah Tangga (IRT). Artinya, yang menggunakan produk rahn tidak hanya untuk wiraswasta saja, tetapi untuk semua jenis pekerjaan. Produk rahn merupakan produk yang mudah dan cepat dilakukan untuk mendapatkan modal tambahan dalam kondisi mendesak. 


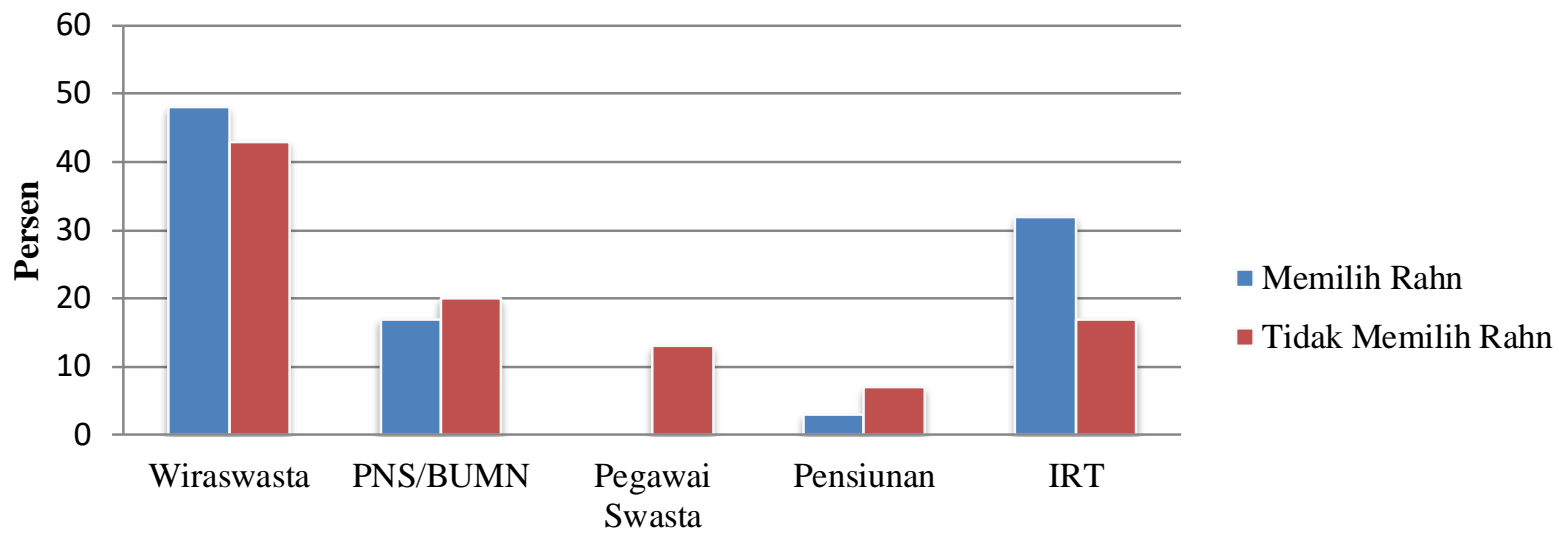

Jenis Pekerjaan

Sumber : Data primer 2019, (diolah)

Gambar 4 Jenis pekerjaan responden

Gambar 4 menunjukkan persentase masing-masing jenis pekerjaan nasabah yang memilih produk rahn dan tidak memilih produk rahn di BPRS Amanah Ummah. Pekerjaan wiraswasta memiliki persentase terbesar sebanyak $48 \%$ atau 29 orang untuk yang memilih produk rahn, sedangkan yang tidak memilih produk rahn sebesar $43 \%$ atau 26 orang. Hal ini menunjukkan bahwa tingginya persentase wiraswasta yang memilih produk rahn salah satunya untuk pertambahan modal usaha, pembelian aset, dan kebutuhan lainnya.

Pegawai swasta merupakan jenis pekerjaan terendah untuk nasabah yang memilih produk rahn sebesar $0 \%$ atau 0 orang. Sedangkan yang tidak memilih produk rahn yaitu pensiunan sebesar $7 \%$ atau 4 orang. Hal ini menunjukan bahwa seseorang yang telah atau sedang bekerja di suatu lembaga cenderung untuk belum memilih produk rahn untuk mendapatkan dana tambahan di saat kondisi mendesak.

\section{Hasil Analisis Faktor-faktor yang Memengaruhi Preferensi Nasabah terhadap Produk Rahn}

\section{Regresi logistik}

Hasil penduga parameter pada Tabel 6 menunjukkan bahwa model dapat mengklasifikasikan responden yang memilih produk rahn sebesar $85 \%$ dan tidak memilih rahn sebesar $81.7 \%$. Model ini mampu mengklasifikasikan secara keseluruhan responden yang menjadi nasabah yang memilih produk rahn dan yang tidak memilih rahn di BPR Syariah Amanah Ummah sebesar 83.3\%.

Tabel 6 Hasil pendugaan parameter logit

\begin{tabular}{ccccc}
\hline \multirow{2}{*}{ Observasi } & \multicolumn{3}{c}{ Prediksi } \\
\cline { 3 - 4 } & & \multicolumn{2}{c}{ Keputusan Nasabah } & \multirow{2}{*}{$\begin{array}{c}\text { Percentage } \\
\text { Correct }\end{array}$} \\
\cline { 2 - 3 } & & $\begin{array}{c}\text { Tidak Memilih } \\
\text { Rahn }\end{array}$ & Memilih Rahn & Comen \\
\cline { 2 - 3 } Keputusan & Tidak Memilih Rahn & 51 & 9 & 85 \\
Nasabah & Memilih Rahn & 11 & 49 & 81.7 \\
\hline \multicolumn{2}{c}{ Overall Percentage } & & & 83.3 \\
\hline
\end{tabular}

Sumber : Data primer, 2019 (diolah)

Faktor-faktor yang memengaruhi preferensi nasabah terhadap produk rahn dapat dilihat pada Tabel 7 yang merupakan hasil regresi logistik. Hasil tersebut menunjukkan bahwa variabel pengetahuan berpengaruh positif dan signifikan terhadap produk rahn pada taraf nyata $1 \%$ dengan nilai odds ratio sebesar 2.642. Artinya, semakin tinggi pengetahuan nasabah terhadap produk rahn maka semakin 
besar peluang untuk memilih produk rahn yaitu mencapai 2.642 kali dari pada yang tidak memilih produk rahn.

Hasil tersebut sesuai dengan penelitian yang dilakukan oleh Alwi (2017) yang menyatakan bahwa pengetahuan responden terhadap produk gadai akan memudahkan masyarakat untuk melakukan pembiayaan ulang karena prosesnya yang mudah, cepat dan sesuai dengan syariat Islam. Selain itu, Pradhanawati (2011) menyatakan bahwa perilaku masyarakat dipengaruhi oleh potensi dan pengetahuan nasabah dalam memilih rahn. Salah satu potensi yang dapat mendorong nasabah memilih rahn adalah kecepatan dan kemudahan pelayanan, serta tidak adanya riba.

Tabel 7 Faktor-faktor yang memengaruhi preferensi nasabah

\begin{tabular}{cccc}
\hline & \multicolumn{3}{c}{ Metode Logit } \\
\cline { 2 - 4 } & Parameter & P-Value (Sig) & Odds Ratio \\
\hline Pengetahuan & 0.97 & $0.000^{* *}$ & 2.642 \\
Citra Lembaga & -0.09 & 0.549 & 0.913 \\
Aksesibilitas & -0.16 & 0.624 & 0.85 \\
Promosi & -1.36 & $0.000^{* *}$ & 0.257 \\
Pelayanan & 0.59 & $0.000^{* *}$ & 1.804 \\
Jenis Kelamin & -0.22 & 0.292 & 0.802 \\
Umur & -0.08 & 0.128 & 0.923 \\
Tingkat Pendidikan & -0.99 & $0.010^{*}$ & 0.372 \\
Pekerjaan & 0.99 & $0.005^{*}$ & 2.686 \\
Pendapatan & 0.00 & $0.001^{* *}$ & 1.000 \\
Pengeluaran & 0.00 & $0.006^{*}$ & 1.000 \\
Jumlah Tanggungan & 1.02 & $0.040^{*}$ & 2.761 \\
\hline
\end{tabular}

Ket: *Signifikan pada taraf nyata $5 \%$, **Signifikan pada taraf nyata $1 \%$

Sumber: Data primer, 2019 (diolah)

Tabel 7 menunjukkan bahwa variabel promosi dan pelayanan berpengaruh positif dan signifikan terhadap pemilihan produk rahn pada taraf nyata $1 \%$. Nilai odds ratio untuk variabel promosi sebesar 0.257 , yang artinya semakin besar promosi yang dilakukan BPRS untuk produk rahn maka semakin kecil peluang nasabah memilih produk rahn adalah sebesar 0.257 kali daripada yang tidak memilih produk rahn. Kemudian, odds ratio untuk variabel pelayanan adalah sebesar 1.804, yang artinya semakin tinggi pelayanan yang dilakukan oleh BPRS terhadap produk rahn maka semakin besar pula peluang nasabah untuk memilih produk tersebut sebesar 1.804 .

Semakin baik tingkat pelayanan dan promosi yang dilakukan, maka nasabah akan cenderung memilih BPRS Amanah Ummah. Hasil ini sesuai dengan penelitian yang dilakukan oleh Azizah (2018) dan Safi'i (2011) yang menyatakan bahwa variabel pelayanan (pelayanan yang memuaskan, dikelola secara profesional dan lain-lain) dan promosi merupakan faktor-faktor yang memengaruhi preferensi nasabah untuk menggadaikan barangnya di lembaga keuangan syariah. Tingkat pelayanan dan tingkat promosi yang tinggi akan memengaruhi dan menyakini nasabah bahwa lembaga keuangan syariah memiliki keunggulan dari berbagai aspek.

Variabel tingkat pendidikan berpengaruh negatif dan signifikan terhadap pemilihan produk rahn pada taraf nyata 5\%, dengan nilai odds ratio sebesar 0.372. Artinya, semakin tinggi tingkat pendidikan responden maka peluangnya 0.372 kali lebih kecil untuk memilih produk rahn. Hal ini menunjukkan bahwa semakin tinggi tingkat pendidikan nasabah, maka akan lebih cenderung untuk memilih produk yang berada di BPRS salah satunya produk rahn. Hasil ini sesuai dengan penelitian yang dilakukan oleh Azizah (2018) dan Zaenudin (2006), yang menyatakan bahwa pendidikan merupakan salah satu faktor yang memengaruhi preferensi masyarakat untuk melakukan gadai syariah, karena tingkat 
pendidikan yang tinggi akan membuat masyarakat peduli terkait sistem dan proses operasional yang sesuai berdasarkan prinsip syariah.

Variabel pekerjaan berpengaruh positif dan signifikan terhadap pemilihan produk rahn pada taraf nyata $1 \%$ dengan nilai odds ratio sebesar 2.686. Artinya, semakin lama responden bekerja maka semakin besar pula peluang responden untuk memilih produk rahn di BPRS mencapai 2.686 kali. Tingginya persentase pekerjaan menunjukkan bahwa nasabah yang memilih produk rahn salah satunya untuk pertambahan modal usaha, investasi dan kebutuhan lainnya.

Variabel pendapatan dan pengeluaran berpengaruh positif dan signifikan terhadap pemilihan produk rahn pada taraf nyata 5\% dengan nilai odds ratio yang sama yaitu sebesar 1.000 untuk variabel pendapatan dan pengeluaran. Artinya, semakin besar pendapatan atau pengeluaran seseorang maka semakin besar pula peluang untuk memilih produk rahn sebesar 1.000 kali. Hal ini sesuai dengan penelitian Haris (2015) yang menyatakan bahwa produk-produk bank syariah lebih diminati oleh kalangan berpenghasilan menengah ke bawah karena didukung dengan adanya sistem jemput bola yang merupakan andalan utama dalam melayani nasabah (terutama BPRS) yang sangat diminati masyarakat di kalangan tersebut.

Variabel jumlah tanggungan berpengaruh positif dan signifikan pada taraf nyata 5\% dengan nilai odds ratio sebesar 2.761. Artinya, semakin tinggi jumlah tanggungan maka semakin banyak kebutuhan yang dikeluarkan maka peluangnya sebesar 2.761 kali lebih besar untuk memilih produk rahn. Hal ini menunjukkan bahwa semakin banyak jumlah tanggungan seseorang, maka semakin banyak pula keperluan akan dana tambahan untuk memenuhi kebutuhannya.

\section{SIMPULAN}

Karakteristik responden yang memilih dan tidak memilih produk rahn dibagi menjadi dua, yaitu karakteristik berdasarkan aspek sosial dan karakteristik berdasarkan aspek ekonomi. Karakteristik berdasarkan aspek sosial menunjukkan bahwa sebagian besar responden yang memilih produk rahn berada pada rentang usia 31 sampai 40 tahun, sedangkan usia yang tidak memilih produk rahn berada pada rentang usia 20 sampai 30 tahun. Berdasarkan jenis kelamin, mayoritas perempuan yang memilih produk rahn dan yang tidak memilih produk rahn. Berdasarkan tingkat pendidikan, mayoritas yang memilih dan tidak memilih produk rahn didominasi oleh SMA. Berdasarkan jumlah tanggungan, mayoritas responden dengan jumlah tanggungan keluarga sebanyak 4 orang memilih produk rahn. Sedangkan mayoritas responden dengan jumlah tanggungan keluarga sebanyak 3 orang tidak memilih produk rahn.

Karakteristik berdasarkan aspek ekonomi menunjukkan bahwa rata-rata pendapatan responden yang memilih produk rahn berada dalam rentang 1 juta rupiah sampai 5 juta rupiah per bulan. Sedangkan yang tidak memilih produk rahn berada dalam rentang 5 juta rupiah sampai 10 juta rupiah per bulan. Berdasarkan pengeluaran, responden yang memilih maupun tidak memilih produk rahn berada pada rentang 1 juta rupiah sampai 5 juta rupiah per bulan. Tingginya persentase wiraswasta menunjukkan bahwa nasabah yang memilih produk rahn salah satunya untuk pertambahan modal usaha dan kebutuhan lainnya.

Hasil analisis metode regresi logistik menunjukkan bahwa variabel pengetahuan, promosi, pelayanan, tingkat pendidikan, pekerjaan, pendapatan, pengeluaran dan jumlah tanggungan berpengaruh secara signifikan dalam menentukan keputusan responden dalam memilih produk rahn. Sementara variabel citra lembaga, aksesibilitas dan umur tidak berpengaruh secara signifikan. Hal ini menunjukkan semakin tinggi variabel yang signifikan maka semakin tinggi pula peluang responden untuk memilih produk rahn. 


\section{DAFTAR PUSTAKA}

[BPS] Badan Pusat Statistik Indonesia. (2018). Jumlah penduduk Indonesia, 2018 [Internet]. [diunduh 2018 Des 26]. Tersedia pada: https://www.bps.go.id.

[BPS] Badan Pusat Statistik Kabupaten Bogor. (2018). Jumlah penduduk dan laju pertumbuhan penduduk menurut kabupaten/kota di kabupaten Bogor, 2014, 2015, 2016, 2017, dan 2018 [Internet]. [diunduh 2018 Des 24]. Tersedia pada: https://bogorkab.bps.go.id.

[PBI] Peraturan Bank Indonesia. (2009). Tentang Bank Pembiayaan Rakyat Syariah [Internet]. [diunduh 2019 Mar 10]. Tersedia pada: https://www.bi.go.id.

Alwi, S. (2017). Motivasi nasabah terhadap pembiayaan gadai emas pada Bank Syariah Mandiri Cabang Bone. [tesis]. Makassar, UIN Alauddin.

Azizah, A. (2018). Analisis sistem dan faktor-faktor yang memengaruhi preferensi nasabah terhadap rahn di pegadaian syariah (kasus PT. Pegadaian Syariah Cabang Cinere). [skripsi]. Bogor, Institut Pertanian Bogor.

Firdaus, M. \& Harmini, A.F. (2011). Aplikasi Metode Kuantitatif untuk Manajemen dan Bisnis. Bogor (ID), IPB Press.

Haris, M. (2015). Analisis faktor-faktor yang memengaruhi preferensi nasabah terhadap bank syariah di DKI Jakarta. [skripsi]. Bogor, Institut Pertanian Bogor.

Howard, J. A. (1989). Consumer Behavior in Marketing Strategy. Englewood Cliffs (NJ), PrenticeHall.

Huda, N \& Heykal, M. (2010). Lembaga Keuangan Islam Tinjauan Teoritis dan Praktis: Panduan Riset dan Kajian. Jakarta (ID), Kencana.

Jannah, A.R. (2018). Implementasi marketing mix (7P'S) dalam meningkatkan jumlah nasabah produk rahn di Pegadaian Syariah Kantor Cabang Sidoarjo. [disertasi]. Surabaya, UIN Sunan Ampel.

Mubarak, Z. \& Windasari, I. (2014). Faktor-faktor yang mempengaruhi perilaku konsumen dalam memilih pegadaian syariah di Kota Banjarmasin. At-Taradhi: Jurnal Studi Ekonomi, 4(1).

Kotler, P. (2000). Manajemen Pemasaran (Edisi Bahasa Indonesia). Jakarta (ID), Salemba Empat.

Pradhanawati, A. (2011). Potensi dan preferensi terhadap perilaku memilih pegadaian syariah. Jurnal Bisnis dan Manajemen, 12(1), 1-7.

Safi'i, M.A. (2011). Preferensi nasabah terhadap gadai emas syariah (studi kasus gadai emas di BRI Syariah Cabang Yogyakarta). [tesis]. Yogyakarta, UIN Sunan Kalijaga.

Said, N.S. (2010). Analisis pengaruh lokasi dan pelayanan pegadaian syariah terhadap minat nasabah (studi kasus Pegadaian Syariah Cab. Depok). [skripsi]. Jakarta, UIN Syarif Hidayatullah.

Sari, M. \& Sudardjat, I. (2013). Persepsi masyarakat tentang gadai emas di Pegadaian Syariah Cabang Setia Budi Medan. Jurnal Ekonomi dan Keuangan, 1(2).

Setyo, B. (2010). Kedudukan gadai syariah (rahn) dalam sistem hukum jaminan Indonesia. Jurnal Dinamika Hukum, 10(1), 21-27.

Siregar, B.G. (2018). Pengaruh produk dan promosi terhadap keputusan menjadi nasabah tabungan marhamah pada Pt. Bank Sumut Cabang Syariah Padangsidimpuan. TAZKIR: Jurnal Penelitian Ilmu-ilmu Sosial dan Keislaman, 4(1), 1-20.

Sugiyono. (2011). Metode Penelitian Administrasi. Bandung (ID), Alfabeta.

Surahman, M. \& Adam, P. (2018). Penerapan prinsip syariah pada akad rahn di Lembaga Pegadaian Syariah. Law and Justice, 2(2), 135-146.

Yasmin, N. \& Effendi, J. (2017). The effect of internal and external factor of banking to the SMEs financing for BPRS in Indonesia. Jurnal Keuangan dan Perbankan, 21(3).

Zaenudin. (2006). Preferensi masyarakat terhadap gadai syariah pada Kantor Cabang Pegadaian Syariah Margonda Depok tahun 2005. [tesis]. Depok, Universitas Indonesia. 